\title{
PENGARUH KOMPRES ALOE VERA TERHADAP FLEBITIS AKIBAT PEMASANGAN INFUS (IV LINE)
}

\author{
FRISKA ERNITA SITORUS ${ }^{1}$, ELOK LIDIYA WATI ${ }^{2}$
}

\author{
1,2 INSTITUT KESEHATAN DELI HUSADA DELI TUA \\ Jl.Besar No.77 Deli Tua Kec.Delitua, Kab.Deli Serdang Sumatera Utara \\ email: friskasitorus87@gmail.com
}

DOI : https://doi.org/10.35451/jkf.v2i1.265

\begin{abstract}
Phlebitis can cause thrombus and embolism which can cause permanent damage to the vein and can cause infection if not treated properly. The aim of the study was to determine the effect of giving Aloe Vera gel on the scale of phlebitis. The study design used one group pretest-posttest. The variables in this study are Aloe Vera compresses as independent variables and phlebitis as the dependent variable. The population in this study were all patients who experienced phlebitis at Sembiring General Hospital in 2019. Sampling using Consecutive sampling techniques as many as 31 respondents. Data were collected by observation sheet of phlebitis scale and tested with Wilcoxon statistical test. The results showed that there was a change in the scale of phlebitis experienced by respondents who experienced changes from respondents who had not previously found that there were no symptoms of phlebitis after being given aloe vera compresses. Wilcoxon statistical test result show data $\rho$-value $0.000<a 0.05$ then $\mathrm{Ho}$ is rejected and $\mathrm{Ha}$ is accepted, which means that there is a significant effect between aloe vera compresses to changes in the degree of phlebitis. Any changes that occur in patients who have experienced phlebitis indicate that giving aloe vera compresses can indicate the results of changes that are quite effective. It is expected that health workers can apply non-pharmacological therapies such as aloe vera compresses for the treatment of phlebitis so that the services provided can be of higher quality and the services performed more precisely.
\end{abstract}

Keywords : Aloe vera, Phlebitis, Pemasangan Infus

\section{Pendahuluan}

Terapi intravena fluid drop (IVFD) merupakan salah satu tindakan yang sering dilakukan di rumah sakit. Tindakan pemasangan infus harus benar-benar mengikuti Standard Operasional Prosedur (SOP) agar angka kejadian infeksi akibat pemasangan infus dapat bekurang dan bahkan tidak terjadi. (Priharjo, 2008).

Terapi intravena fluid drop (IVFD) adalah terapi yang bertujuan untuk memasukkan sejumlah cairan kedalam tubuh, melalui jarum, ke pembuluh darah vena (pembuluh darah balik) untuk mengganti sejumlah cairan dan zat-zat makanan yang hilang dalam tubuh. Manfaat terapi intravena adalah untuk memperbaiki ketidakseimbangan cairan dan elektrolit dalam tubuh. (Potter and Perry, 2005).

Jumlah kejadian penyakit flebitis menurut Distribusi Penyakit Sistem Sirkulasi Darah Pasien Rawat Inap di Indonesia tahun 2008 berjumlah 744 orang atau sekitar $(17,11 \%)$ (Depkes RI, 2008). Hasil penelitian Depkes RI 
Received: 25 September 2019 :: Accepted: 26 Oktober 2019:: Published: 31 Oktober 2019

tahun 2013 angka kejadian flebitis di Indonesia sebesar 50,11\% untuk rumah sakit pemerintah dan untuk rumah sakit swasta sebesar 32,70\% (Rizky W, 2014).

Hasil penelitian lain yang dilakukan oleh Pujasari dan Sumarwati (2002) menyatakan bahwa angka kejadian flebitis di salah satu rumah sakit di Jakarta sekitar $10 \%$. Menurut Uslosoy (2008), penelitian yang dilakukan pada 20 orang pasien rawat inap yang terpasang infus di Puskesmas Krian sidoarjo, 14 orang pasien diantaranya mengalami flebitis. Dari banyaknya jenis infeksi Nasokomial Flebitis berada pada peringkat pertama daripada infeksi Nasokomial lainnya (Depkes RI, 2013).

Flebitis adalah iritasi pada tunika intima vena yang di sebabkan oleh faktor kimia, mekanis, bakteri, dan post infusion yang menyebabkan efek nyeri, eritema, bengkak dan hangat pada bagian penusukan, pembentukan lapisan, dan pengerasan sepanjang vena (Alexander, et al, 2010; Foster, wallis, Paterson, \& James, 2002). Hal ini di karakterisktikkan dengan adanya daerah yang memerah dan terasa panas didaerah penusukan vena, nyeri di daerah penusukan vena, dan pembengkakan (Brunner \& Suddarth, 2013). Banyak faktor yang menyebabkan terjadinya flebitis pada pasien yang terpasang infus diantaranya kesterilan atau aseptic saat pemasangan infus, kesalahan dalam mendesinfeksi sebelum menusukkan kateter intravena pada daerah penusukan dengan alkohol 75\%, kesterilan alat-alat yang digunakan sangat berperan dalam mencegah komplikasi inflamasi pada vena, seperti: mencuci tangan sebelum melakukan tindakan, desinfeksi daerah yang akan di tusuk (Brunner dan Suddart, 2013). Jenis terapi, prosedur pemasangan, kualitas kateter intravena dan status penyakit pasien berpengaruh terhadap kejadian flebitis (Premeji, 2007; Hasanah, et al. 2017).

Terjadinya flebitis dapat menghambat tindakan medis melalui vena, akses cairan, obat dan nutrisi yang akan diberikan pada pasien, selain itu flebitis juga dapat menyebabkan peningkatan resiko infeksi dan bahkan sepsis. Tindakan medis yang sering dilakukan untuk mengatasi flebitis adalah dengan menggunakan kompres alkohol $70 \%$ dan Larutan garam $0.9 \%$. Beberapa peneliti menggunakan bahan non farmakologi untuk mengurangi derajat flebitis salah satunya dengan meggunakan tanaman tradisional aloe vera atau lebih di kenal masyarakat lidah buaya.

Bagian yang berkhasiat dari aloe vera sebagai obat ialah isi dari daun yang tebal dan kenyal seperti daging yang juga berbentuk seperti gel atau jelly, yakni semacam lendir yang kental dan padat.Pada saat ini gel aloe vera telah banyak dimanfaatkan secara luas, tidak lagi hanya untuk obat luar, tetapi telah digunakan mengobati luka dalam, seperti radang saluran pencernaan. Gel juga di sebut mampu menyejukkan dan mendinginkan, atau berfungsi untuk meredakan rasa panas serta nyeri akibat peradangan dan luka-luka. Gel aloe vera pun di percaya mampu menjaga kelembaban kulit, sehingga kulit tidak mudah menjadi kering, keriput, ataupun bersisik. Menurut para ahli, hal tersebut karena dalam gel aloe vera terdapat zat lignin yang berkhasiat menberikan kelembaban pada kulit.

Peneliti yang berasal dari Cina telah membuktikan bahwa aloe vera bermanfaat untuk pencegahan dan penyembuhan flebitis (Zhang et al. 2014). Peneliti lain juga mempublikasikan bahwa dengan mengkompres aloe vera dan campuran gliserin dan magnesium sulfat dapat 
Received: 25 September 2019 :: Accepted: 26 Oktober 2019:: Published: 31 Oktober 2019

menurunkan derajat flebitis (Suzanna et al. 2014; Hasannah et al. 2017).

Pemberian kompres aloe vera dianggap lebih aman digunakan menurunkan derajat flebitis serta memiliki banyak keunggulan diantaranya aloe vera mudah di temukan, tidak banyak menimbulkan efek samping, tidak menimbulkan ekstravasasi pada pembuluh darah karena tidak memiliki elektrolit dalam konsentrasi tinggi (Zheng, et al, 2014). Dari survei awal yang dilakukan oleh peneliti diperoleh $40 \%$ pasien mengalami flebitis dari 100 pasien selama 6 bulan terakhir. Dari penjelasan di atas maka peneliti awal ini bertujuan melakukan penelitian Pengaruh kompresaloe vera terhadap kejadian flebitis akibat pemasangan infus (IV line) di Rumah Sakit Umum SembiringKec. Delitua tahun 2019.

\section{Metode}

Desain penelitian ini yaitu pre eksperimental dengan rancangan one grup pretest and posttest desain. Variabel dalam penelitian ini yaitu kompres Aloe Vera sebagai vaiabel independen dan flebitis sebagai variabel dependen. Populasi dalam penelitian ini yaitu seluruh pasien yang mengalami flebitis di Rumah Sakit Umum Sembiring Kecamatan Deli Tua Kabupaten Deli Sedang tahun 2019. Sampel diambil dengan menggunakan tekhnik Consecutive sampling sebanyak 31 orang responden. Data dikumpulkan dengan lembar observasi skala flebitis dan diuji dengan uji statistik wilcoxon. Waktu penelitian dilaksanakan pada bulan November sampai dengan bulan Juni 2019 di Rumah Sakit Umum Sembiring Kecamatan Deli Tua Kabupaten Deli Serdang tahun 2019.

\section{Hasil}

Tabel 1. Skala Flebitis Sebelum Diberikan kompres Aloe Vera

\begin{tabular}{cccc}
\hline No. & Pre Test & $\mathrm{f}$ & $\%$ \\
\hline 1. & Derajat 1 & 1 & 3,2 \\
2. & Derajat 2 & 10 & 32,3 \\
3. & Derajat 3 & 14 & 45,2 \\
4. & Derajat 4 & 6 & 19,4 \\
\hline & Total & 31 & 100,0 \\
\hline
\end{tabular}

Berdasarkan analisa univariat berdasarkan analisa derajat flebitis sebelum diberikan kompres Aloe Vera pada pasien Flebitis didapatkan hasil bahwa mayoritas derajat 3 sebanyak 14 orang dengan persentase $45,2 \%$.

Tabel 2. Skala Flebitis Sesudah Diberikan kompres Aloe Vera

\begin{tabular}{llcc}
\hline NO. & Postest & f & \% \\
\hline 1. & Derajat 0 & 7 & 22,6 \\
2. & Derajat 1 & 12 & 38,7 \\
3. & Derajat 2 & 12 & 38,7 \\
\hline & Total & $\mathbf{3 1}$ & $\mathbf{1 0 0 , 0}$ \\
\hline
\end{tabular}

Berdasarkan analisa univariat berdasarkan analisa derajat flebitis sesudah diberikan kompres Aloe Vera pada pasien Flebitis didapatkan hasil bahwa mayoritas derajat 2 sebanyak 12 orang dengan persentase $38,7 \%$.

Perubahan skala flebitis pada pasien sebelum dan sesudah diberikan kompres Aloe Vera.

Tabel 3. Analisis Pengaruh Kompres Aloe Vera Terhadap Flebitis

\begin{tabular}{lllllll}
\hline No. & N & Mean & S.D & Min & Max & $\begin{array}{c}\rho \\
\text {-value }\end{array}$ \\
\hline $\begin{array}{l}\text { Pre- } \\
\text { test }\end{array}$ & 31 & 2,81 &, 792 & 1 & 4 & 0,000 \\
$\begin{array}{l}\text { Post- } \\
\text { test }\end{array}$ & 31 & 1,16 &, 779 & 0 & 2 & \\
\hline
\end{tabular}

Berdasarkan data analisa bivariat hasil dari uji statistik diperoleh Mean 
Received: 25 September 2019 :: Accepted: 26 Oktober 2019:: Published: 31 Oktober 2019

Pretest adalah 2,81 dan posttest 1,16 yang berarti rata-rata kejadian flebitis sebelum diberikan kompres Aloe Vera adalah 2,81 dan rata-rata kejadian flebitis setelah diberikan kompres Aloe Vera 1,16 sehingga dapat diketahui bahwa penurunan sebesar 1,65. Berdasarkan analisis bivariat hasil uji statistik $\rho$-value $0,000<$ a 0,005 maka Ho ditolak dan Ha diterima yang artinya adanya pengaruh yang signifikan antara kompres Aloe Vera terhadap perubahan derajat flebitis pada pasien flebitis akibat pemasangan infus (IV Line).

\section{Pembahasan}

1. Skala Flebitis Pada Pasien Sebelum Diberikan Kompres Aloe Vera

Hasil penelitian yang dilakukan di Rumah Sakit Umum Sembiring Kecamatan Deli Tua Kabupaten Deli Serdang terhadap 31 responden yang mengalami Flebitis sebelum diberikan kompres Aloe Vera diperoleh data berdasarkan tabel 4.4 diperoleh data bahwa hampir setengah responden mengalami flebitis derajat 3 sebanyak 14 responden $(45,2 \%)$.

Flebitis merupakan suatu peradangan pada pembuluh darah (vena) yang dapat terjadi karena adanya injury misalnya oleh faktor (trauma) mekanik dan faktor kimiawi, yang mengakibatkan terjadinya kerusakan pada endotelium dinding pembuluh darah khususnya vena. Flebitis dikarakteristikkan dengan adanya dua atau lebih tanda nyeri, kemerahan, bengkak, indurasi, dan serta mengeras dibagian vena yang terpasang kateter intravena (Smeltzer \& Bare, 2001). Flebitis juga dikarakteristikkan dengan adanya rasa lunak pada area insersi atau sepanjang vena. Flebitis merupakan inflamasi vena yang disebabkan oleh iritasi kimia maupun mekanik. Hal ini ditunjukkan dengan adanya daerah yang merah nyeri dan pembengkakan didaerah penusukan atau sepanjang vena. Insiden flebitis meningkat sesuai dengan lamanya pemasangan jalur intravena. komplikasi cairan atau obat yang diinfuskan (terutama $\mathrm{PH}$ dan tonsisitasnya), ukuran dan tempat kanula yang dimasukkan (Brunner \& Sudarth, 2002). Menurut Potter \& Perry (2009) skala flebitis terbagi menjadi 5 dengan tanda dan gejala yang berbedabeda.

Hasil penelitian pada tabel 4.4 menunjukan hasil sebagian responden mengalami flebitis derajat 3 , sifat nyeri dan eritema pada lokasi suntikan menyebabkan seseorang merasa tidak nyaman. Keterlibatan peneliti dalam interaksi dengan responden dapat mengidentifikasi tanda dan gejala dari flebitis. responden yang mengalami flebitis disebabkan oleh saat tindakan pemasangan infus terjadi pecahnya vena, saat aktivitas yang berlebih menggunakan tangan yang terpasang infus dan prosedur pengobatan dari cairan dengan menggunakan konsentrasi yang pekat, sehingga mudah terjadi flebitis pada tempat pemasangan infus namun flebitis yang terjadi pada responden tidak mengalami komplikasi yang lebih lanjut. Hasil penelitian sejalan dengan hasil penelitian yang dilakukan oleh Binarti Dwi W. (2015), mayoritas responden mengalami flebitis derajat 3 sebelum diberikan perlakuan.

Berdasarkan data distribusi faktor usia responden pada tabel 4.1 menunjukkan bahwa mayoritas berumur 46-55 tahun (22,6\%). Hal tersebut sejalan dengan hasil penelitian Binanrti Dwi $W$ yang menunjukkan hasil bahwa mayoritas responden berusia 40-60 tahun $(42,1 \%)$. Dan Hasil penelitian diatas juga selajan dengan hasil penelitian yang dilakukan oleh Mulyadi (2014) yang menunjukkan mayoritas 
Received: 25 September 2019 :: Accepted: 26 Oktober 2019:: Published: 31 Oktober 2019

pasien berumur 41-50 tahun (43,3\%). Penelitian tersebut menunjukkan bertambahnya usia seseorang akan mengalami beberapa perubahan dalam diri mereka secara fisiologis dan psikologis, diantara perubahan fisiologis tersebut adalah perubahan pada mekanisme kardiovaskuler sehingga dapat menyebabkan terjadinya seperti peningkatan tekanan darah dan perubahan struktur pembuluh darah seperti vena. Karakteristik skala flebitis yang dialami responden sebelum diberikan kompres Aloe Vera sangat bervariasi karena dengan gejala yang sesuai tingkat flebitis yang dialami, sehingga dapat menimbulkan karakteristik derajat flebitis yang berbeda beda.

Hasil penelitian dari 31 responden yang mengalami flebitis mayoritas berjenis kelamin perempuan sebanyak 19 orang dengan persentase $61,3 \%$. Dan minoritas berjenis kelamin laki-laki sebanyak 12 orang dengan persentase $38,7 \%$. Terdapat beberapa faktor karakteristik responden yang dapat mempengaruhi terjadinya flebitis seperti jenis kelamin dan pengalaman sebelumnya terjadi flebitis, responden dengan karakteristik perempuan akan meningkatkan resiko terjadinya flebitis saat pemasangan kateter infus atau pemberian obat medis dengan konsentrasi tinggi karena struktur vena pada perempuan lebih lunak dan mudah pecah daripada vena laki-laki. Sedangkan dari beberapa responden yang pernah mengalami flebitis sebelumnya akan merubah struktur vena yang menjadi lebih lemah, sehingga dapat mempengaruhi skala terjadinya flebitis.

Berdasarkan hasil penelitian yang dilakukan terhadap 31 responden terdapat mayoritas dengan kategori bekerja sebanyak 18 orang dengan persentase $58,1 \%$ dan minoritas dengan kategori tidak bekerja sebanyak 13 orang dengan persentase 41,9\%. Responden dengan karakteristik dengan kategori bekerja lebih beresiko mengalami flebitis karena lebih memiliki struktur vena yang menonjol akibat aktivitas berat.

Hasil penelitian yang dilakukan terhadap 31 responden sebelum diberikan kompres Aloe Vera diperoleh derajat flebitis dengan skala 1 sebanyak 1 orang dengan persentase 3,2\%, derajat 2 sebanyak 10 orang dengan persentase 32,3, derajat 3 sebanyak 14 orang dengan persentase $45,2 \%$ dan derajat 4 sebanyak 6 orang dengan persentase $19,4 \%$. Setelah diberikan kompres Aloe Vera diperoleh hasil derajat flebitis dengan skala 0 sebanyak 7 orang dengan persentase 22,6\%, skala 1 sebanyak 12 orang dengan persentase $38,7 \%$, dan skala 2 sebanyak 12 orang dengan persentase $38,7 \%$.

2. Skala Flebitis pada Pasien Sesudah diberikan Kompres Aloe Vera

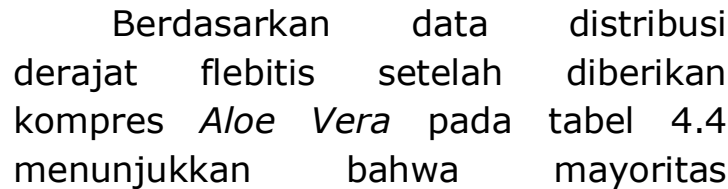
responden mengalami flebitis derajat 2 sebanyak 12 orang $(38,7 \%)$ dan derajat 1 sebanyak 12 orang $(38,7 \%)$ dan tidak ada gejala flebitis sebanyak 7 orang (22.6\%).

Dalam respon inflamasi, Aloe Vera menghasilkan Bradikinin yang dapat menurunkan skala nyeri, mengandung luteol, beta sitosterol, compesterol, yaitu suatu steroid alami yang berperan kuat dalam anti inflamasi, mengandung asam salisilat yang menghambat prostaglandin pada reaksi inflamasi, menghambat carboxypeptidase, suatu senyawa glikoprotein yang efektif dalam mengurangi nyeri akibat inflamasi. 
Received: 25 September 2019 :: Accepted: 26 Oktober 2019:: Published: 31 Oktober 2019

Kemudian juga mengandung polisakarida yang menstimulasi fibrolas untuk regenerasi dan penyembuhan jaringan (Binarty Dwi W, 2015). Aloe Vera merupakan obat herbal yang dapat menyembuhkan berbagai luka karena mengandung antimikroba, antikuman, antifural, dan antiinflamasi, Aloe Vera mengandung fotokimia yang diteliti untuk bioaktivitas seperti polymannas, mannas asetat, antrakuinon, Cglikosida, dan berbagai lektin (Boudreau, 2006).

Setelah diberikan kompres Aloe Vera skala flebitis mengalami penurunan karena efek Aloe Vera dapat menjadi anti mikroba, menghambat terjadinya inflamasi, memberi perasaan nyaman, merangsang pengeluaran endhorpins dan menghambat pengeluaran prostrglandin. Nilai penurunan skala flebitis setelah diberikan kompres Aloe Vera berbedabeda karena setiap individu dapat menghasilkan kadar endhorpins dan reaksi inflamasi yang berbeda-beda. Flebitis yang disertai oleh infeksi akan membutuhkan waktu yang lama dalam penyembuhannya, karena fungsi fisiologis tubuh yang meningkat.

3. Perubahan Skala Flebitis Pada Pasien Sebelum dan Sesudah diberikan Kompres Aloe Vera

Berdasarkan data distribusi tabel 4.6 diatas menunjukkan bahwa terjadi perubahan pada skala flebitis yang dialami oleh responden mengalami perubahan, dari responden yang sebelumnya memiliki derajat 0 flebitis tidak ada setelah diberikan kompres Aloe Vera responden yang memiliki derajat 0 terdapat 7 responden, pada flebitis derajat 1 mengalami peningkatan dari 1 responden menjadi 12 responden, pada flebitis derajat 2 mengalami peningkatan dari 10 responden menjadi 12 responden, sedangkan pada flebitis tingkat 3 mengalami penurunan dari 14 responden menjadi 0 responden dan pada flebitis derajat 4 mengalami penurunan dari 6 responden menjadi 0 responden.

Hasil uji Wilcoxon menunjukkan data bahwa $\rho=0,000$ dan $a=0,05$ sehingga $\rho<$ a maka ho ditolak dan ha diterima sehingga ada pengaruh yang signifikan terhadap pemberian kompres Aloe Vera terhadap flebitis di Rumah Sakit Umum Sembiring Kecamatan Deli Tua Kabupaten Deli Serdang.

Ekstrak Aloe Vera memiliki aktivitas antibakteri dan anti jamur, yang dapat membantu mengobati infeksi kulit kecil seperti bisul dan kista kulit jinak dan dapat menghambat pertumbuhan jamur yang menyebabkan tinea (Shamin et al., 2014). Beberapa penelitian menunjukkan bahwa Aloe Vera mempercepat tingkat penyembuhan. Pengunaan Aloe Vera juga efektif untuk herpes genital dan psoriasis (Maenthaisong et al., 2010). Dalam uji coba, Double blind klinis, kedua kelompok menggunakan Aloe Vera mengandung pasta gigi dan kelompok yang menggunakan gigi flouride mengalami penurunan dari ginggivitas dan plak, tetapi tidak ada perbedaan statistik yang signifikan ditemukan antar keduanya (Olivera, et al., 2010; Feily et al., 2012). Dalan penelitian berikutnya ekstrak Aloe Vera telah terbukti dapat menyembuhkan flebitis lebih cepat dibanding dengan kompres alkohol 70\% (Rajin \& Indah 2014).

Perubahan skala flebitis yang terjadi pada responden penelitian ini dapat menunjukkan bahwa penurunan skala pada masing-masing responden sangan bervariasi, hal itu sangat erat terkait dengan faktor-faktor yang mempengaruhi terjadinya flebitis dan 
Received: 25 September 2019 :: Accepted: 26 Oktober 2019:: Published: 31 Oktober 2019

respon tubuh terhadap inflamasi saat flebitis yang dibawa oleh responden baik dari responden sendiri maupun dari lingkungan luar. Namun dilihat dari perubahan yang terjadi terapi pemberian kompres Aloe Vera dapat menunjukkan hasil perubahan yang cukup efektif.

\section{Kesimpulan}

Berdasarkan hasil penelitian ini dapat disimpulkan bahawa Umur responden yang mengalami flebitis diperoleh mayoritas lansia awal (46-55 tahun) sebanyak 7 orang dengan persentase 22,6\%. Jenis kelamin responden diperoleh mayoritas berjenis kelamin perempuan sebanyak 19 orang dengan persentase $61,3 \%$. Pekerjaan responden diperoleh mayoritas dengan kategori bekerja sebanyak 18 orang dengan persentase $58,1 \%$. Derajat flebitis sebelum diberikan kompres Aloe Vera pada pasien Flebitis didapatkan hasil mayoritas derajat 3 sebanyak 14 orang dengan persentase 45,2\%. Dan derajat flebitis sesudah diberikan kompres Aloe Vera pada pasien Flebitis didapatkan hasil mayoritas derajat 2 sebanyak 12 orang dengan persentase $38,7 \%$. Hasil uji wilcoxon umtuk derajat flebitis di Rumah Sakit Umum Sembiring diperoleh nilai $\rho$-value $0,000<$ a 0,005 maka Ho ditolak dan Ha diterima yang artinya ada pengaruh yang signifikan antara kompres Aloe Vera terhadap derajat flebitis di Rumah Sakit Umum Sembiring.

\section{Daftar Pustaka}

Binarti, Dwi. W. (2015), Pengaruh Pemberian Gel Aloe Vera terhadap Skala Phlebitis Pada Pasien Rawat Inap. Jurnal Keperawatan Bina Sehat PPNI Mojokerto. Hal. 1-7

Liang Ma. Zheng. (2017) Peripheral Venous Catheter-Related
Adverse Events: Evaluation from a multicentre epidemiological study in france (the CATHEVAL Project). Jurnal Nanjing Univercity Medical school China. Hal. 117

Maenthaisong R, Chaiyakunapruk N, Niruntraporn S et al. 2007. 'The efficafy of ole vera for burn wound healing: a systematic review". Burn33 (6): 713-718.

Oktafiani, N., Nurbaya, S., \& Hadia (2013). Pengarh pemberian kompres air hangat dan terapi antibiotic terhadap peyembuhan Phlebitis di ruagan Perawatan Anak RSUD Daya Makassar. Diperoleh dari http://library.stikesnh.ac.id/. Tanggal 10 Desember 2018.

Purbaya.J.Rio. 2011. Mengenal dan memanfaatkan khasiat Aloe Vera. Bandung: Pionir Jaya

Potter, PA, Perry AG. 2009. Foundamental Of Nursing, $7^{\text {th }}$ Edition, Alih Bahasa : Diah, dkk. Salemba Medika : Jakarta.

Premji, R. (2007). Frech Medical Institute for Children (FMIC) :A study on incidences of Phlebitis and causes in pediatric patients at FMIC, Afghanistan. Diperoleh dari http://www.stti.iupui.edu/pp0 7/congress10/premji_.pdf.

Shamim S, Ahmed S. W., Azhar I.1 2004. Antifungal activity of Allium, Aloe and Solanum Species" Pharmaceutical Biology.

Smeltzer S, \& G Bare. 2001, Buku Ajar Keperawatan Medical Bedah. Edisi 8 Volum 3. Jakarta : EGC

Sumara, Retno (2017), Hubungan Lokasi Terapi Intravena Dengan Kejadian Flebitis. 
Received: 25 September 2019 :: Accepted: 26 Oktober 2019:: Published: 31 Oktober 2019

Jurnal Keperawatan

Muhammadiyah Surabaya.

Hal. 127-134.

Suzanna. J.D., D' Souuza. S.W., \& Malarvizhi. M (2014). Effectiveness of fresh Aloe Vera and glycerine magnesium sulphate: Application on phlebitis among children. International Journal of Current Research. Diperoleh dari

http://www.journalcra.com/sit es/default/files/5659_0.pdf.
Uslosoy, E., \& Mete, S. (2008). Predisposing Factors to Phlebitis in patients with paripheral intravenous catheter: A descriptive study. Journal of the American Academy of Nurse Practitioners, 20 (4), 172-180.

Zheng, G. H., Yang, L., Chen, H. Y., Chu, J. F., \& Mei L. (2014). Aloe Vera for prevention and treatment of infusion phlebitis. Cochrane Database Syst Rev (6). 